\title{
EDITORIAL
}

\section{Applications of emerging technologies to the study of human genetics}

The last several years have seen the explosive growth of major new technologies some of which are a result of collaborative initiatives involving chemists, physicists, engineers, molecular geneticists as well as computer programmers and software developers. Many of these advances have resulted in start-up companies (A ffymetrix, Inc., Caliper Technology Corporation, Genometrix, Inc., N anogen, Inc., Synteni, Inc., etc) whose focus is to capitalize and expand on these technologies for commercial use. DNA 'chips', as they are commonly called, promise to facilitate cost-effective, parallel array processing for the purposes of mutation and polymorphism detection, definition of gene expression profiles, microsatellite genotyping, defining gene organization and mapping as well as DNA sequence analysis, to mention only a few potential uses.

Front-end microchip systems are being developed capable of isolating particular cells mechanically (eg human lymphocytes) or electronically (eg bacteria)., ${ }^{1,2}$ The isolated cells can be used directly for PCR reaction (in the case of lymphocytes) or subjected to electronic lysis before PCR or other amplification technology is applied. ${ }^{3,4}$ The amplicons are then examined by chip capillary electrophoresis or other analyses on a chip..$^{5-7}$ Some of these approaches involve use of silicon-based technologies which have been previously confined to use in the semiconductor industry. ${ }^{8} \mathrm{~N}$ ew materials like polycarbonate may soon expand the utility of this approach.

Protocols are available for precise deposition and/or synthesis of nuclei acids onto a microarray which can be the size of a computer chip. ${ }^{9-11}$ These chips with bound probes can then be used for interrogation by labeled targets, which when annealed to their complementary matches, result in the in-place formation on a chip of hybrids which can be detected using highly sensitive sophisticated imaging systems.

Sensitivities approaching detection of 0.1 attomoles in a spot at a particular register on a chip have been reported. Non-chip based approaches are also being used (eg SAGE, differential displays, etc) to analyze gene expression profiles, and they promise to add to our knowledge of the regulated expression of genes in normal and diseased states. ${ }^{12,13}$ I nitial reports also show the potential of $3 \mathrm{D}$ reconstruction of gene expression profiles in the developing human embryo. ${ }^{14} \mathrm{~N}$ on-gel based approaches to DNA sequence analysis and microsatellite genotype analysis are also well along in development. Finally, new approaches using 2D gels and mass spectral analysis of derived peptides from the individual electropherogram spots hold promise for facilitating detailed information on protein expression patterns in a variety of different cells. ${ }^{15}$

The European Journal of Human Genetics recognizes these highly promising newly emerging technologies and now solicits submission of original manuscripts detailing these new and other advances and their application to the study of human genetics.

Paolo Fortina

D epartment of Pediatrics, U niversity of Pennsylvania School of Medicine, The Children's H ospital of Philadelphia, Philadelphia, PA, U SA

\section{References}

1 Cheng J, Kricka LJ, Sheldon EL, Wilding P: Sample preparation in microstructured devices. In: Manz A, Becker $H$ (eds): Microsystems Technology in Chemistry and L ife Science. Current Topics in Chemistry. SpringerVerlag: Heidelberg, 1997, vol 194: pp 215-231.

2 Wilding P, Pfahler J, B au HH, Zemel JW, K ricka LJ: $M$ anipulation and flow of biological fluids in straight channels micromachined in silicon. Clin Chem 1994; 40: 43-47.

3 Northrup MA, Ching MT, White RM, Watson RT: DNA amplification in a microfabricated reaction chamber. In: Transducers ' 93 7th International Conference on Solid State Sensor, A ctuators 7-10 J une 1993; Y okohama, Japan, pp 924-926.

4 Cheng J, Shoffner M A, H vichia GE, K ricka LJ, Wilding P: Chip PCR (II): investigation of different PCR amplification systems in micro-fabricated silicon-glass chips. Nucleic A cids Res 1996; 24: 380-385.

5 Woolley AT, M athies RA: U Itra-high-speed DNA fragment separations using microfabricated capillary array electrophoresis chips. Proc Natl A cad Sci USA 1994; 91: 11348-11352. 
6 E ditorial: to affinity ... and beyond. $\mathrm{N}$ at $\mathrm{G}$ enet 1997; 14: 367-370.

7 Sosnowski R G, Tu E, Butler W F, O 'C onnell J P, H eller M J: $R$ apid determination of single base mismatch mutations in DNA hybrids by direct electric field control. Proc Natl A cad Sci USA 1997; 94: 1119-1123.

8 Fodor SPA, R ead J L, Pirrung M C, Stryer L, Lu A T, Solas $D$ : Light-directed, spatially addressable parallel chemical synthesis. Science 1991; 251: 767-773.

9 Lockhart DJ, Dong H, Byrne MC et al: Expression monitoring by hybridization to high-density oligonucleotide arrays. Nature B iotech 1996; 14: 1675-1680.

10 Schena M, Shalon D, D avis RW, B rown PO : Q uantitative monitoring of gene expression patterns with a complementary DNA microarray. Science 1995; 270: 467-470.
11 Southern EM, Maskos U, Elder JK: A nalyzing and comparing nucleic acid sequences by hybridization to arrays of oligonucleotides: evaluation using experimental models. G enomics 1992; 13: 1008-1017.

12 Velculescu VE, Z hang L, Vogelstein B, K inzler K W: Serial analysis of gene expression. Science 1995; 270: 484-487.

13 Sagerstrom CG, Sun BI, Sive HL: Subtractive cloning: past, present, and future. Ann Rev Biochem 1997; 66: 751-783.

14 Strachan T, A bitbol M, D avidson D, Beckmann J S: A new dimension for the human genome project: towards comprehensive expression maps. Nat Genet 1997; 16: 126-132.

15 R oepstorff $P$ : M ass spectrometry in protein studies from genome to function. Curr O pin B iotech 1997; 8: 6-13. 